\title{
KARAKTERISTIK AKSEPTOR KB SUNTIK DI BIDAN PRAKTEK MANDIRI (BPM) SUMAYA AGUSTINA S.ST CISARUA BOGOR 2016
}

\section{ACCEPTOR KB ACTIVITY CHARACTERISTICS IN BIDAN PRAKTEK MANDIRI (BPM) SUMAYA AGUSTINA S.ST CISARUA BOGOR 2016}

\author{
Siti Rafika Putri \\ Akademi Kebidanan Al-Ikhlas Cisarua Bogor
}

\begin{abstract}
ABSTRAK
Menurut WHO, diperkirakan adalah 460 juta, atau sekitar 51\% dari pasangan yang beresiko hamil. Metode spesifik yang digunakan adalah Sterilisasi Wanita Sukarela 26\%, Alat Kontrasepsi Dalam Rahim (AKDR) 19\%, Kontrasepsi Oral 15\%, Sterilisasi Pria Sukarela 10\%, Kondom 10\%, Koitus Interuptis 8\%, Metode Keluarga Berencana Alami 7\%, Metode Sawar Vagina $2 \%$, Kontrasepsi Suntik $1 \%$, metode lain 2\%. Tujuan umum penelitian ini adalah untuk mengetahui gambaran karakteristik akseptor KB Suntik di BPM Sumaya Agustina,S.ST Cisarua Bogor. Variabel yang diteliti meliputi usia, paritas, pekerjaan dan pendidikan dari Aseptor KB suntik di BPM Sumaya Agustina,S.ST Cisarua Bogor. Dengan populasi seluruh Akseptor KB Suntik sejumlah 804 Akseptor dan sampel yang diteliti sebanyak 268 Akseptor. Tekhnik pengambilan sampel dengan cara simple random sampling. Karakteristik Akseptor KB suntik di BPM Sumaya Agustina,S.ST didapatkan terbanyak pada akseptor dengan karakteristik usia 2035 tahun (82.2\%), paritas Multi-Grande (56\%), Pendidikan SD-SMP-SMA (92.2\%) dan Akseptor yang tidak bekerja (78.7\%).
\end{abstract}

Kata Kunci : KB Suntik, Usia, Paritas, Pekerjaan, Pendidikan

\begin{abstract}
According to WHO, it is estimated to be 460 million, or about $51 \%$ of couples at risk of becoming pregnant. Specific methods used are Voluntary Women Sterilization 26\%, Intrauterine Contraception (IUD) 19\%, Oral Contraception 15\%, Voluntary Men Sterilization 10\%, Condoms 10\%, Interruptis Coitus 8\%, Natural Family Planning Method 7\%, Bidding Method Vagina $2 \%$, Injectable Contraception $1 \%$, other methods $2 \%$. The general purpose of this research is to know the description of the characteristics of KB contraceptive acceptor in BPM Sumaya Agustina, S.ST Cisarua Bogor. The variables studied included age, parity, occupation and education from Injecting FP Injectors at BPM Sumaya Agustina, S.ST Cisarua Bogor. With a population of accepting injectors of 804 acceptor and 268 acceptor samples. Technique of sampling by simple random sampling. The characteristics of the injecting contraceptive in BPM Sumaya Agustina, S. ST were obtained mostly on acceptors with characteristics of age 20-35 years (82.2\%), Multi-Grande parity (56\%), Education SD-SMP-SMA (92.2\%) and Acceptor not working $(78.7 \%)$.
\end{abstract}

Keywords: Family Planning, Age, Parity, Occupation, Education 


\section{PENDAHULUAN}

Pengguna akseptor KB di Indonesia sampai Maret 1999 adalah KB Suntik 34,8\%, Pil 28,3\%, IUD 19,3\%, Implant 19,8\%, Kontap 5,5\%, lain 1,2\% (Manuaba, 2008). Program KB menjadi gerakan $\mathrm{KB}$ yang ditujukan terutama untuk meningkatkan kualitas sumber daya manusia dilandasi oleh Undang-undang No. 10 tahun 1992 tentang kependudukan dan keluarga sejahtera. Program KB di Indonesia mengalami perkembangan pesat, ditinjau dari sudut, tujuan, ruang lingkup geografi, pendekatan, cara operasional, dan dampaknya terhadap pencegahan kelahiran. Penurunan tingkat kelahiran, yaitu dengan menetapkan target penurunan 50\% dari 44 pada tahun 1971 menjadi 22 pada tahun 1990 (Saifudin,2010). Badan Pusat Statistik (BPS) melaporkan berdasarkan data Susenas 2014 dan 2015, jumlah penduduk Indonesia mencapai 254,9 juta jiwa. Data BPS menunjukkan, dari total tersebut, penduduk laki-laki mencapai 128,1 juta jiwa sementara perempuan sebanyak 126,8 juta jiwa (Handayani, 2013).Berdasarkan Survei Demografi dan Kesehatan Indonesia (SDKI) 2012, sebanyak $62 \%$ peserta KB menggunakan alat kontrasepsi modern dan tradisional. Pengguna IUD baru $4 \%$, susuk $3 \%$, suntik $32 \%$, dan pil 14\%. Hal ini mengakibatkan angka kelahiran di Indonesia tinggi. Jumlah kelahiran di Indonesia pada 2014 mencapai 4 juta bayi per tahun dengan angka kelahiran 2,6. "Pada 2025, kami menargetkan angka kelahiran menurun jadi 2,1. Dengan angka itu, baru tercapai program dua anak cukup pada KB” (Setyawati, 2010).

Penyebaran penduduk menurut pulau-pulau besar adalah: pulau Sumatera yang luasnya $25,2 \%$ dari luas seluruh wilayah Indonesia dihuni oleh $21,3 \%$ penduduk, Jawa yang luasnya 6,8 $\%$ dihuni oleh $57,5 \%$ penduduk, Kalimantan yang luasnya $28,5 \%$ dihuni oleh 5,8 \% penduduk, Sulawesi yang luasnya 9,9\% dihuni oleh 7,3\% penduduk, Maluku yang luasnya 4,1 \% dihuni oleh $1,1 \%$ penduduk, dan Papua yang luasnya $21,8 \%$ dihuni oleh $1,5 \%$ penduduk (Setyaningrum, 2010). Pencapaian peserta KB di dunia pada Pasangan Usia Subur (PUS) sekitar $56 \%$ pasangan dengan rata-rata anak 2,7 orang dan telah menekan pertumbuhan penduduk menjadi 1,9/tahun. Sekalipun telah melampaui perhitungan fase transisi pertumbuhan penduduk, tetapi jumlahnya masih belum sanggup didukung oleh kemampuan negara untuk memberikan berbagai fasilitas (Manuaba, 2008). Hasil yang didapatkan akan berguna untuk mengetahui karakteristik responden dalam hal ini usia, pekerjaan, paritas, dan pendidikan klien yang menjadi akseptor KB Suntik. Hal ini bertujuan untuk meningkatkan minat pemakaian KB suntik.

\section{METODE PENELITIAN}

\section{Alat dan Bahan}

Sampel penelitian ini adalah Sebagian Akseptor KB Suntik di BPM Sumaya Agustina sebanyak 268 orang. Populasi dalam penelitian ini adalah seluruh ibu akseptor KB suntik di BPM Sumaya Agustina S.ST Cisarua Bogor tahun 2016 sebanyak 804 orang.

\section{Metode}

Penelitian ini merupakan penelitian deskriptif analitik untuk menggambarkan karakteristik akseptor KB suntik di BPM Sumaya Agustina S.ST Cisarua Bogor. Pengambilan data dilakukan secara retrospektif di BPM Sumaya Agustina S.ST Cisarua Bogor. Penelitian ini menggunakan Simple Random Sampling.

\section{Analisis data}

Penelitian ini menggunakan analisis univariat sehingga diperoleh nilai frekuensi dari karakteristik pasien meliputi usia, pekerjaan, paritas, dan pendidikan klien yang menjadi akseptor KB Suntik di BPM Sumaya Agustina S.ST Cisarua Bogor. 


\section{HASIL DAN PEMBAHASAN}

Pada penelitian ini, penulis mendapatkan data bahwa kelompok akseptor KB Suntik berdasarkan Usia di BPM Sumaya Agustina S.ST Cisarua Bogor tahun 2016 adalah kelompok usia 20-35 tahun sebanyak 222 (82,8\%) Akseptor KB Suntik. Sedangkan usia< 20->35 tahun sebanyak 46 (17,2\%) Akseptor KB Suntik. Usia mempengaruhi akseptor dalam penggunaan alat kontrasepsi dari faktor-faktor usia dapat ditentukan fase-fase. Usia kurang 20 tahun fase menunda kehamilan, usia antara 20-30 tahun fase menjarangkan kehamilan, usia antara 30 tahun lebih fase mengakhiri kehamilan.

Kelompok akseptor KB Suntik berdasarkan Paritas di BPM Sumaya Agustina S.ST Cisarua Bogor tahun 2016 adalah paritas primigravida sebanyak 118 (44\%) Akseptor KB Suntik. Sedangkan paritas Multi Gravida- Grande Gravida sebanyak 150 (56\%) Akseptor KB Suntik. Hasil penelitian ini ditemukan sesuai dengan teori yaitu menurut Prawirohardjo (1999), yang menyatakan bahwa seorang ibu berparitas tinggi apabila jumlah anaknya lebih dari 3, paritas 2-3 merupakan paritas yang paling aman ditinjau dari sudut kematian maternal. Lebih tinggi paritas akseptor KB maka lebih tinggi pula resiko terjadinya kematian maternal. Resiko kematian maternal dapat dicegah atau dikurangi dengan menjadi akseptor KB.

Kelompok akseptor KB Suntik berdasarkan Pendidikan di BPM Sumaya Agustina S.ST Cisarua Bogor tahun 2016 adalah Pendidikan Wajib ( SD, SMP, SMA) sebanyak 247 (92,2\%) Akseptor KB Suntik. Sedangkan Pendidikan Tinggi sebanyak 21 (7,8\%) Akseptor KB Suntik. Berdasakan teori bahwa makin tinggi tingkat pendidikan seseorang makin mudah menerima informasi sehingga makin banyak pula pengetahuan yang dimiliki (Nursalam. 2001). Sebaliknya pendidikan yang kurang akan menghambat perkembangan sikap seseorang tehadap nilai-nilai yang baru diperkenalkan (Nursalam dan Siti Pariani 2001).

Kelompok akseptor KB Suntik berdasarkan Pekerjaan di BPM Sumaya Agustina S.ST Cisarua Bogor tahun 2016 adalah Bekerja sebanyak 57 (21,3\%) Akseptor KB Suntik. Sedangkan Tidak Bekerja sebanyak 211 (78,7\%) Akseptor KB Suntik. Pekerjaan adalah kegiatan yang dilakukan dan mendapatkan upah. Pekerjaan seseorang akan menggambarkan aktivitas dan kesejahteraan ekonomi yang akan didapatkan (Haryanti, 2010). Menurut penelitian Asri Septyarum \& Sri Subiyatun tahun 2014. Hasil uji statistic bahwa tidak terdapat hubungan pekerjaan dengan pemilihan kontrasepsi Suntik karena biasanya ibu yang bekerja tidak selalu menjarakan atau menunda kehamilan.

\section{KESIMPULAN}

Karakteristik Akseptor KB suntik di BPM Sumaya Agustina,S.ST didapatkan terbanyak pada akseptor dengan karakteristik usia 20-35 tahun (82.8\%), paritas Multi-Grande (56\%), Pendidikan SD-SMP-SMA (92.2\%) dan Akseptor yang tidak bekerja (78.7\%). Saran dari hasil penelitian ini bagi setiap akseptor KB adalah agar lebih memahami tentang KB Suntik baik cara penggunaan maupun efek samping yang dialami oleh ibu.

\section{DAFTAR PUSTAKA}

Affandi,B. 2011,Buku Panduan Praktis Pelayanan Kontrasepsi Edisi 3. Jakarta : PT Bina Pustaka Sarwono Prawiharji.

Handayani,S. 2013.Buku ajar pelayanan keluarga berencana. Yogyakarta: Pusataka Rihana

Manuaba, I.B.G. 2008. Ilmu Kebidanan, Penyakit Kandungan,dan Keluarga Berencana untuk Pendidikan Bidan. Penerbit EGC,Jakarta.

Saifuddin,A.B. 2010, Buku panduan praktis Pelayanan Kontrasepsi Edisi 2.Jakata : PT Bina Pustaka Sarwono Prawihardjo 
Setiyawati,N. 2010.Pelayanan Keluarga berencana. Yogyakarta : Citramaya.

Melania. 2010.Pelayanan Keluarga Berencana. Yogyakarta : Citramaya.

Notoatmodjo,S. 2010.Metodologi Penelitian Kesehatan.Jakarta : Rineka cipta

Alexandra.2011.Ekonomi.Diunduhmelalui:http://alexandraaboutme.blogspot.com/2011/06/arti ekonomi.html. Diakses pada tanggal : 13/01/2017

Andayani,D. 2013. Faktor-faktor yang Berhubungan dengan Minat Ibu dalam Menggunakan Alat Kontrasepsi Implant di Wilayah Kerja Puskesmas Ingin Jaya Kabupaten Aceh Besar. Diunduh melalui :http://180.241.122.205/docjurnal/DIAN_ANDAYANIjurnal_dian.pdf.Diakses pada tanggal 13/01/2017

Setiyaningrum,E.2014.Pelayanan Keluarga Beencana dan Kesehatan Reproduksi. Jakarta : CV. Trans Info Media. 